\title{
Assessment of the lowa River's South Fork watershed: Part 2. Conservation practices
}

\author{
M.D. Tomer, T.B. Moorman, D.E. James, G. Hadish, and C.G. Rossi
}

\begin{abstract}
Documenting the types and extent of conservation practices in a watershed is necessary to determine their water quality impacts. A conservation practice inventory for the South Fork of the Iowa River, 85\% in corn (Zea mays L.) and soybean [Glycine max L. (Merr.)] rotations, showed only $7 \%$ of cropland was managed using no-tillage. About 30\% of cropland receives manure annually, prior to corn. Surface residue following soybean was usually inadequate $(<30 \%)$, indicating a key management challenge. About $90 \%$ of fields with $>34 \%$ highly erodible land, subject to USDA conservation compliance, indeed had erosion-control practices installed. Grassed waterways and riparian buffers were common edge-of-field practices, and highly erodible land fields near streams often had multiple practices and rotations including third crops. Yet, while most conservation practices are aimed at controlling runoff, tile drainage is the dominant hydrologic pathway. Resource management systems that address tile drainage as the primary route of nutrient loss need to be developed and encouraged. Better targeting of this pathway could include practices such as nutrient removal wetlands.
\end{abstract}

Key words: Conservation Effects Assessment Project (CEAP) - conservation practicesnutrient management - tillage practices - water quality

\begin{abstract}
Agricultural conservation practices (CPs) have been widely adopted across the United States, due at least in part to USDA financial incentives and availability of technical assistance from the Natural Resources Conservation Service (NRCS). Impacts of CPs on hydrologic processes and water quality have been the subject of a breadth of research (Schnepf and Cox 2007). Yet most of this reported research has been conducted at plot and field scales, which leads to uncertainty for drawing inferences at watershed scales. Recently, efforts have begun to understand the environmental implications of distributions of CPs in watersheds. The need to target conservation and/or nutrientmanagement practices to environmentally 'sensitive' areas of the landscape is increasingly being recognized. Targeting of conservation programs at specific resource concerns or site conditions can influence program effectiveness (Hatch et al. 2001; Johansson and Randall 2003; Yang et al. 2005). Walter et al. (2007) summarized the growing litera-
\end{abstract}

may help determine if and how future revision of conservation policies should have a greater emphasis on targeting.

This paper provides an assessment of agricultural land uses and CPs within the Iowa River's South Fork watershed in north-central Iowa. The South Fork of the Iowa River drains a 78,000 ha $(193,000 \mathrm{ac})$ watershed in north-central Iowa. In a companion paper (Tomer et al. 2008), we provide a description of the watershed and show that the South Fork and its tributaries contain significant amounts of phosphorus, $\mathrm{NO}_{3}-\mathrm{N}$ and Escherichia coli. Here our objective is to describe the extent and placement of key CPs in the watershed and evaluate the results in the context of four years of concurrent, detailed water quality data. We consider the distribution of a variety of CPs relative to distributions of erodible soils, proximity to streams, and areas where manure applications are most likely.

\section{Materials and Methods}

Background. To the best of our knowledge, practices present in the South Fork watershed were generally encouraged through prevailing conservation policy in Iowa. Practices have been implemented through USDA conservation compliance and Conservation Reserve Program (CRP), modest investments from other USDA programs such as the Environmental Quality Incentives Program (EQIP), and state conservation funding available throughout Iowa. The watershed has not been involved with the Conservation Security Program, is not a drinking water source, and is not on Iowa's listing of impaired waters (under Clean Water Act, Section 303d). It thereby provides a normative setting to evaluate implementation and effects of CPs under intensive agricultural production with tile drainage as the dominant source of nutrient loading (Tomer et al. 2008).

Land Use and Crop Rotations. Conservation practices need to be assessed in the context rather than policy (Robinson and Napier 2002). While current policy requiring erosion control on erodible lands is accepted by producers (Hatch et al. 2001), one remote sensing study indicated the spatial distribution of conservation tillage in a Minnesota watershed was little influenced by topography (Gowda et al. 2003). Further assessment of targeting under current conservation policy, emphasizing protection of erodible lands and voluntary implementation of practices,
Mark D. Tomer is a soil scientist, Thomas B. Moorman is a microbiologist, and David E. James is a GIS specialist at the National Soil Tilth Laboratory, USDA Agricultural Research Service, Ames, lowa. Greg Hadish is a geographic analyst with USDA Natural Resources Conservation Service, Des Moines, lowa. Colleen G.Rossiisasoilscientistatthe Blacklands Research Center, USDA Agricultural Research Service, Temple, Texas. 
of other agricultural land use data, particularly crop rotations and livestock production. Cropping rotations were determined using annual classified satellite data made available by the USDA National Agricultural Statistics Service (NASS) (USDA NASS 2007). The satellite data are subject to a supervised classification aimed to identify commodity-crop acreages (i.e., corn and soybean in Iowa) with minimal error. Five years of classified data (2000 to 2004) were overlaid to map the dominant crop rotations occurring on agricultural lands within the watershed. Agricultural field boundaries, provided by the USDA Farm Service Agency, were used as a majority filter for each year of crop-cover data to provide a single five-year sequence of cover for each field. The observed cropcover sequences were then grouped to represent dominant rotations in the watershed, including two-year (corn-soybean), three-year (corn-corn-soybean), and longer rotations based on number of consecutive years with corn up to five years (ie., continuous corn). Fields with sequences dominated by grass (pasture) were assigned as permanent cover, and perennial rotations were assigned to fields where the crop sequence included a third crop (in addition to corn and soybean) because the third crop was typically classified as alfalfa or hay in the NASS data. Non-agricultural lands were not considered in this assessment but included grasslands, forest, wetlands, and urban land (including farmsteads and roadways).

The assigned crop rotations were further classified to indicate where either manure or commercial fertilizer applications would be expected. Animal feeding operations were digitized using rectified infrared aerial photographic imagery acquired in May 2002 by Iowa's Department of Natural Resources (Iowa State University 2002) and geographic information system (GIS) software (Environmental Systems Research Institute 2002). The size (total floor area) of the buildings in each confinement was calculated from the digitized data. All confinements were assumed to produce swine, with deep-pit manure storage, and wean-tofinish feeding operation. This type of feeding operation is the most common, and nearly all produce swine. About 60 of 110 confinements lacked external manure storage (i.e., lagoons were not shown on the air photos) and are presumed to be deep pits. Assuming one animal per $0.75 \mathrm{~m}^{2}\left(8.1 \mathrm{ft}^{2}\right)$ of floor area in the confinements at full operation (B. Kerr, USDA Agricultural Research Service, personal communication, April 2004) and nutrient excretion rates per animal per day of $23 \mathrm{~g} \mathrm{~N} \mathrm{~d}^{-1}$ and $18 \mathrm{~g} \mathrm{P} \mathrm{d}^{-1}\left(0.8 \mathrm{oz} \mathrm{N} \mathrm{day}^{-1}\right.$ and $0.6 \mathrm{oz} \mathrm{P} \mathrm{day}{ }^{-1}$ ) in deep-pit manure (Lorimer et al. 2000), the load of nutrients produced by each operation assuming full livestock occupancy could be calculated. Allowing for $5 \% \mathrm{~N}$ loss due to ammonia volatilization during application with incorporation (Lorimer 2003), this resulted in $10.5 \mathrm{~kg} \mathrm{~N} \mathrm{y}^{-1} \mathrm{~m}^{-2}$ and $6.6 \mathrm{~kg} \mathrm{P} \mathrm{y}^{-1}$ per $\mathrm{m}^{-2}\left(2.1 \mathrm{lb} \mathrm{N} \mathrm{y}^{-1} \mathrm{ft}^{-2}\right.$ and $1.3 \mathrm{lb} \mathrm{P} \mathrm{y}^{-1} \mathrm{ft}^{-2}$ ) of building area available for application to corn in the watershed annually, assuming no import or export across the watershed boundary.

The distribution of manure applications within the watershed was estimated using a GIS model that divided the $\mathrm{N}$ load from each facility by the areas of increasingly sized circles (in 40-m [131-ft] radius increments, without overlap) until the area within the circle accommodated the $\mathrm{N}$ load at an application rate of $200 \mathrm{~kg} \mathrm{~N} \mathrm{ha}^{-1}\left(179 \mathrm{lb} \mathrm{ac}^{-1}\right)$ for corn. The application rates assigned to fields within the circles were varied to account for the observed crop rotation by assigning the full rate to fields where three or more consecutive years of corn and half the rate where 2- or 3-year corn-soybean rotations were observed. This essentially assumes manure application occurs prior to corn and not prior to soybean. This model was written in ARC programming language (Environmental Systems Research Institute 2002).

Conservation Practices. An inventory of CPs was conducted during the first half of 2005. The inventory was conducted by USDA NRCS and included four steps. First, a search of records of the agency's progress reporting system with contributions from four local NRCS field offices was conducted. Second, aerial photos were interpreted and digitized to map visible CPs such as terraces and grass waterways. Third, a field-by-field, drive-by survey was conducted during May 2005 to provide a snapshot of tillage practices throughout the watershed and confirm the progress reporting system data and air photo interpretations where possible. The survey was conducted by NRCS personnel with knowledge of local tillage systems and experience in estimating residue cover. Data were digitally collected in the field, using tabletstyle, touch-screen computers equipped with global positioning system signal tracking to ensure mapping accuracy. A GIS coverage of the watershed's fields, with field boundaries provided by the USDA Farm Service Agency common land unit system that documents agricultural lands participating in USDA programs, provided the base map for touchscreen linkage to a data-entry interface. Specialized GIS software was developed to expedite the survey process, which included pull-down menus, accessible by field, with tag-lists of common practices and opportunity to annotate the record, correct existing information, and digitize features missing from the office-prepared map coverage that were observed in the field. Four persons, paired in two trucks, completed the field survey in about three weeks. The final step was to combine the survey data entered by crews and build the final inventory product, a completed GIS project detailing practices by field, which excluded all ownership information. Evaluation of CPs in the watershed was conducted by GIS overlay with NRCS Soil Survey Geographic data, particularly highly erodible land (HEL) and hydric soils, stream proximity, and with crop rotations and anticipated manure application areas, determined as described above. All this information was placed onto a single spreadsheet, which was sorted and filtered to determine areas where resource concerns and CPs overlapped.

\section{Results and Discussion}

Land Use and Conservation Practices. Agricultural land covers $96 \%$ of the South Fork watershed, which in turn is dominated by corn and soybean rotations covering nearly $95 \%$ of that agricultural land (figure 1). During 2000 through 2004, NASS crop cover data indicate that two-year rotations, annually alternating between the two crops, were prominent $(62 \%)$. Rotations with two or more years of consecutive corn occurred on about one third of the agricultural land, and rotations that included other crops, which were often noted to have conservation crop rotations (USDA CP 327) in the conservation-practice inventory, occupied only about $1 \%$. Noncropped agricultural land is dominantly under CRP plantings (3.5\%) and small amounts of pastureland (grass).

Assuming an N-based application of 200 $\mathrm{kg}$ manure $\mathrm{N} \mathrm{ha}^{-1}\left(178 \mathrm{lb} \mathrm{ac}^{-1}\right)$ prior to corn and approximately $433,500 \mathrm{~m}^{2}(4,682,000$ $\mathrm{ft}^{2}$ ) of livestock confinements in the watershed, about 22,750 ha $(56,190 \mathrm{ac} ; 30 \%$ of the watershed's agricultural land) was estimated 


\section{Figure 1}

Crop rotations and land cover types found in the South Fork watershed's agricultural land.

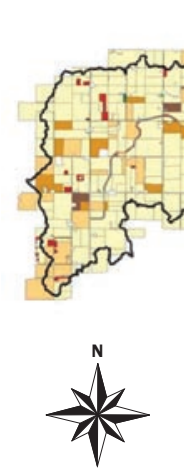

Rotation/cover

Corn-soybean

Corn-corn-soybean

3-to-4-year corn-soybean

Continuous corn

Conservation Reserve Program

Grass

Perennial rotation to receive manure annually. The total area receiving manure is doubled under alternate year applications in a corn-soybean rotation. The results of geographic modeling identify areas most likely to receive manure applications (figure 2), considering corn as the only crop to receive manure. The estimated volumetric rate of slurry application, based on assumed manure excretion rates and nutrient loads, was $39 \mathrm{~m}^{3} \mathrm{ha}^{-1}$, (4,180 gal $\left.\mathrm{ac}^{-1}\right)$, which is in the range reported for confined deep-pit swine operations in this region (Lory et al. 2004).

The survey of CPs showed mulch tillage ( $>30 \%$ residue cover) was the dominant class of residue management (figure 3 and table 1), covering $58 \%$ including one large field (226 ha [558 ac]) under ridge tillage in the Tipton Creek subbasin. Conventional tillage (herein, conventional tillage refers to tillage systems that result in $>70 \%$ of crop residue being incorporated beneath the soil surface) occupied about $29 \%$ of the agricultural land, with no-tillage more limited in extent $(7 \%)$. About $20 \%$ of the cropland is in fields with grassed waterways and/or terraces. There are also water and sediment control structures in 46 fields, protecting 1,185 ha $(2,925 \mathrm{ac})$.

Research in this watershed began partly in response to concerns about livestock confinements and their impacts on water quality. Understanding management practices in fields receiving livestock manure is necessary to understand these impacts. Those fields that lie within the area where manure applications are likely (either wholly or in part), total about 49,100 ha $(121,000$ ac) (figure 2).We summarized rotations and CPs in areas where manure applications are likely and unlikely to occur (table 1). Crop rotation data suggest the "manure-application-likely" fields have a somewhat greater frequency of consecutive years of corn. This would provide greater crop uptake of manure $\mathrm{N}$, and reduce manure transport distances. This area of the watershed also has somewhat less land in permanent cover and rotations with third crops (table 1). Along with rotation, there were also minor differences in residue management between areas dominated by manure applications and by commercial fertilizer. Areas where fields were less likely to be manure amended had greater rates of both no-tillage and conventional tillage ( $<30 \%$ residue cover) practices. The greater rate of conventional tillage occurred despite there being more land subject to conserva- 
tion compliance (fields with $>34 \%$ HEL) where manure was less likely. Although the rate at which fields were protected using terraces or grassed waterways were slightly less in the manure dominated areas (table 1), residue cover was generally well maintained in the group of fields most likely to receive manure applications in this watershed.

The major determinant of residue management class was the prior-year crop (table 2). There was clear evidence that producers find it difficult to maintain crop residue following soybean harvest through to the next planting. Only $36 \%$ of the area in soybean in 2004 (based on processed NASS data) had adequate residue at the next planting. Soybean residue is about $40 \%$ that of corn (Johnson et al. 2006), and much finer and more susceptible to decomposition. Hence soybean was recently identified as a crop that presents a challenge to maintenance of soil organic matter (Johnson et al. 2006). While the proportion of fields with adequate residue was little-influenced by dominance of manure applications (table 2), there is a specific risk where inadequate residue cover occurs following manure application into soybean stubble, especially if $\mathrm{P}$ is also being accumulated in soil. The combination of poor residue cover and high soil $\mathrm{P}$ concentrations compounds the risk of P loss in runoff (Sharpley et al. 2002). Risk of runoff can be influenced by manure application method (Daverede et al. 2004). While we do not have specific data on the application methods in this watershed, a method we commonly observed is a combined surface-band application covered by a single-disk incorporation in one pass.

Evaluation of Conservation Practices Placement. The USDA NRCS has targeted CPs toward HEL since the mid-1980s, under provisions of the Conservation Title of the 1985 Food Security Act (Claassen et al. 2001). Given this policy history, we used the inventory of CPs to determine how successful this ongoing targeting effort has been. Rules under this policy have required implementation of CPs on those fields with $>34 \% \mathrm{HEL}$ in order for the owner to qualify for USDA commodity program support. Our evaluation suggests this effort has been $90 \%$ effective, as discussed below. However, the CP inventory simply offers a "snapshot" of conservationpractice conditions in the watershed, and results must be viewed with recognition that shifts in practices do occur within fields and

\section{Figure 3}

Assessment of tillage practices made in spring 2005.

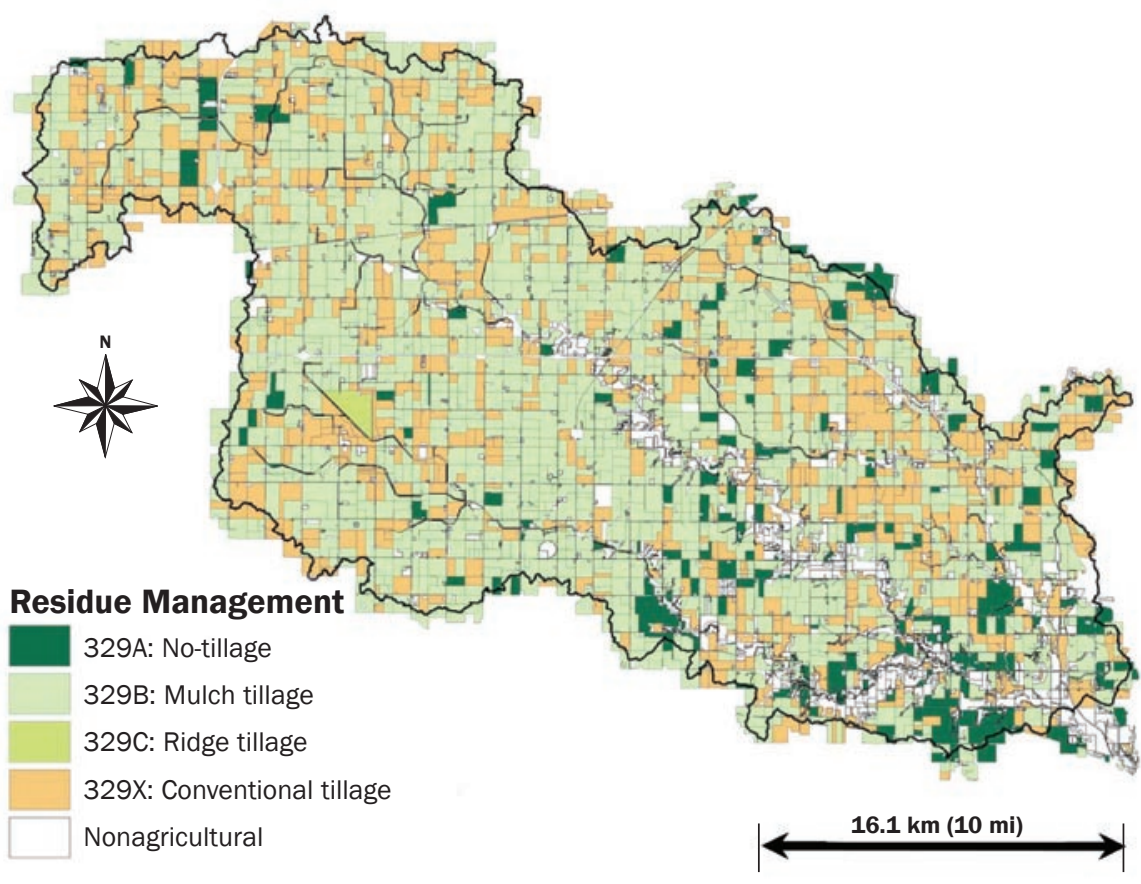

Note: Mulch and conventional tillage are distinguished based on residue cover, more than or less than $30 \%$, respectively.

across the watershed in response to a variety of factors that influence producer decisions about CPs on an ongoing basis.

To summarize the CP inventory data, fields were sorted according to percent of field in HEL based on soil survey (Soil Survey Geographic) data in order of decreasing percentages. Field areas (hectares) were then summed along this sorted order, only including fields where a given CP was present. We began with the practice we expected to provide the best erosion protection, namely CRP (or other permanent cover). We then conducted a second area accumulation, by summing the areas in either CRP or a second practice, in this case a perennial rotation. A third, HEL-sorted summation of areas then included fields in CRP, a perennial rotation, and/or no tillage. A fourth area summation added fields with structural practices (dominantly grass waterways and terraces), and then mulch tillage was added in a fifth summation. No field was counted twice in any summation. The order of practices included in the summations approximately indicates decreasing erosion control. Admittedly the exact order could vary on a field-by-field basis depending on site-specific conditions. The fields not counted in any summations were those observed to have conventional tillage $(<30 \%$ residue) and no observed structural practice. The plotted results of these cumulative summations (figure 4) indeed suggest that conservation treatments (at least one practice) were observed on $90 \%$ of the area subject to conservation compliance. On that small group of cropped fields having more than two thirds HEL, conservation treatments were virtually $100 \%$ present. The area of non-CP treated fields increased from about $10 \%$ to about $20 \%$ of the agricultural lands in the watershed, as the area accumulation included fields with fractions of HEL less than $20 \%$. Of the area without CPs, which totals 15,698 ha $(38,774 \mathrm{ac}), 36 \%$ was in fields with $0 \%$ HEL.

Combinations of CPs probably offer the best erosion protection, and areas with several common combinations are given in table 3. Here, we also extend our sensitive-lands analysis to include those fields that are, at least partly, within $200 \mathrm{~m}$ $(656 \mathrm{ft})$ of a stream (figure 5$)$. This area comprises about $34 \%$ of the agricultural land in the watershed. More than half the watershed's CRP acreage was found near a stream, dominantly as conservation buffers. Also, more than half the agricultural 
Table 1

Extent of crop rotations and selected conservation practices in the lowa River's South Fork watershed.

\begin{tabular}{|c|c|c|c|}
\hline \multirow[b]{2}{*}{ Rotation/class } & \multicolumn{3}{|c|}{ ha (\% of agricultural land) } \\
\hline & Total & Manure likely & Manure not likely \\
\hline Total agricultural land & 74,925 & 49,124 & 25,800 \\
\hline \multicolumn{4}{|l|}{ Crop rotations: } \\
\hline Corn-soybean & $46,295(61.8 \%)$ & $29,768(60.6 \%)$ & $16,528(64.1 \%)$ \\
\hline Corn-corn-soybean & $13,302(17.8 \%)$ & $9,382(19.1 \%)$ & $3,920(15.2 \%)$ \\
\hline 3-to-4-year corn-soybean & $9,299(12.4 \%)$ & $6,998(14.2 \%)$ & $2,301 \quad(8.9 \%)$ \\
\hline Continuous corn (5 year) & $2,031 \quad(2.7 \%)$ & 1,527 (3.1\%) & 504 (2.0\%) \\
\hline Rotations with other crops & 758 (1.0\%) & $229(0.5 \%)$ & 529 (2.0\%) \\
\hline Total cropped area & 71,685 (95.7\%) & $47,904(97.5 \%)$ & $23,782(92.2 \%)$ \\
\hline \multicolumn{4}{|l|}{ Noncropped agricultural land: } \\
\hline Conservation Reserve Program & $2,619(3.5 \%)$ & $1,110 \quad(2.3 \%)$ & $1,509 \quad(5.8 \%)$ \\
\hline Conservation Reserve Program as wetlands & $335(0.4 \%)$ & 222 (0.5\%) & $113(0.4 \%)$ \\
\hline Grass (not Conservation Reserve Program) & $620(0.8 \%)$ & $110(0.2 \%)$ & 510 (2.0\%) \\
\hline \multicolumn{4}{|l|}{ Conservation practices: } \\
\hline Nutrient management plans & $3,694 \quad(4.9 \%)$ & $3,154 \quad(6.4 \%)$ & 539 (2.1\%) \\
\hline No-tillage & $5,409 \quad(7.2 \%)$ & $2,667 \quad(5.4 \%)$ & $2,742(10.6 \%)$ \\
\hline Mulch tillage & $43,501(58.1 \%)$ & $31,261(63.6 \%)$ & $12,239(47.4 \%)$ \\
\hline Conventional tillage & 21,685 (28.9\%) & $13,321(27.1 \%)$ & $8,365(32.4 \%)$ \\
\hline Cropland missing tillage data & $538(0.7 \%)$ & $296(0.6 \%)$ & 241 (0.9\%) \\
\hline Cropped fields with grassed waterways & $10,548(14.1 \%)$ & $6,334(12.9 \%)$ & $4,214(16.3 \%)$ \\
\hline Cropped fields with terraces & 4,655 (6.2\%) & $2,635 \quad(5.4 \%)$ & $2,019 \quad(7.8 \%)$ \\
\hline Subject to conservation compliance (>34\% HEL) & $6,617 \quad(8.8 \%)$ & $3,871 \quad(7.9 \%)$ & 2,746 (10.6\%) \\
\hline
\end{tabular}

Notes: Crop rotation and tillage information are mapped in figures 1 and 2 . The areas likely to receive manure applications are mapped in figure 3. Percentages (in parentheses) refer to fractions of total areas given in the column's first row. HEL = highly erodible land.

Table 2

Residue cover as assessed in 2005 depended on the prior year (2004) crop in areas both likely and unlikely to receive manure applications.

\begin{tabular}{|c|c|c|c|}
\hline 2004 crop/residue class & \multicolumn{3}{|c|}{ ha (\% of 2004 crop area) } \\
\hline 2004 soybean: & 27,632 & 17,151 & 10,481 \\
\hline Inadequate residue $(<30 \%)$ & $17,471(63 \%)$ & $10,652(62 \%)$ & $6,819(65 \%)$ \\
\hline Inadequate residue $(<30 \%)$ & 4,109 (10\%) & 2,643 (9\%) & $1,466(11 \%)$ \\
\hline
\end{tabular}

area in the watershed under permanent cover or perennial crop rotations was near a stream. However, these were fairly small areas. Otherwise, there was little observed increase in the rate of conservation treatments near streams, and about $30 \%$ of the acreage without observed CPs was in fields near a stream. Yet, when we consider those fields both near a stream and having $>34 \%$ HEL, we found evidence of conservation targeting, as $24 \%$ of this land was in permanent cover or a perennial crop rotation, and $28 \%$ had a combination of conservation tillage and structural practices. Nevertheless, nearly $10 \%$ of this erodible, stream-side land appeared to have no conservation treatment, similar to the rate found for the area of all fields subject to conservation compliance. This seems dichotomous but probably reflects the conservation ethic of producers who recognize conservation needs on 
this sensitive land, whereas land retirement (i.e., CRP buffers), virtually the only policy focus of USDA for protecting streamside areas, may little influence those few producers who have not recognized this need.

\section{Summary and Conclusions}

Concern for water quality among agricultural producers has begun to emerge in the Iowa River's South Fork watershed. In 1999, the South Fork Watershed Alliance (SFWA) was formed with the involvement and support of local producers, agribusiness, conservation groups, conservation districts, and local agency personnel. The SFWA formed partnerships that have led to a variety of projects including water quality monitoring, nutrient management demonstrations, watershed assessments, and stream restoration. An increased awareness of water quality problems and their linkage to management practices suggests that progress is being made. However, a minority of producers in the watershed are active in SFWA projects, and wider efforts will be necessary to effectively address water quality issues.

Viewed together, results of the water quality monitoring (Tomer et al. 2008) and the conservation-practice inventory almost seem inconsistent with one another. There are significant water quality problems, yet widespread adoption of CPs. How can this be? We suggest there are three reasons. The first of these is a legacy effect of past practices. The widespread adoption of CPs has a history dating back probably 20 years, and the impetus provided by USDA conservation compliance policies. Conventional tillage certainly would have been the dominant practice in the watershed prior to 1985 and resulted in a significant amount of historical soil erosion. Farmers in the watershed have remarked that water quality in the South Fork is better now than it was in the 1960s and 1970s. This observation probably refers to memories of historically greater turbidity and sediment. Trends of increasing rates of conservation tillage and decreasing sediment and P loads since 1975 have been documented in other areas of the Midwest (Richards and Baker 2002; Richards et al. 2002). Yet, it is important to recognize that eroded soil is dominantly deposited within the watershed and can remain a source of sediment (and hence P) to streams for decades, perhaps many decades (Trimble 1999). Better stream corridor assessment and

\section{Figure 4}

Cumulative land areas protected by erosion-control conservation practices, sorted based on proportion of field that is highly erodible. (a) Areas under a sequence of practices (listed bottom to top in the legend) are summed and plotted (the log scale provides more detail for lands most susceptible to erosion). (b) Lands protected by at least one practice are summed (matching the mulch tillage line in the top graph, with log scale removed), and the lands with no observed conservation at the time of the inventory (2005) are also indicated.

(a)

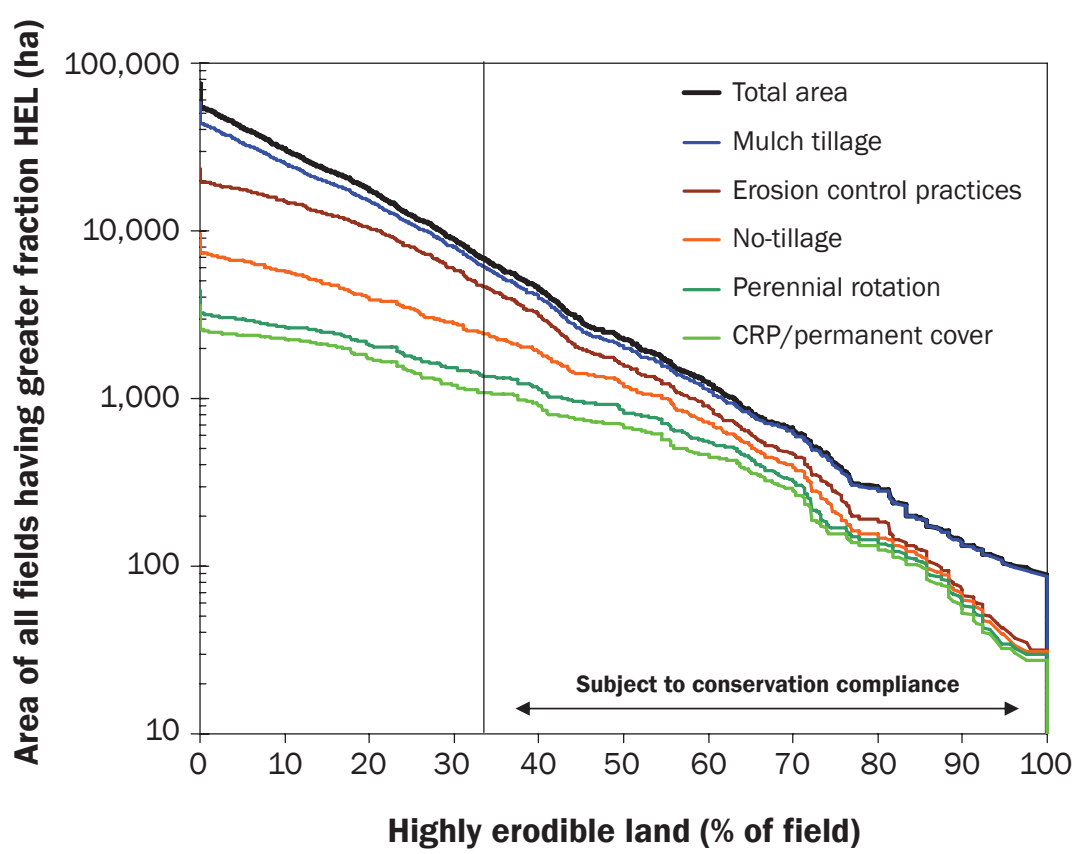

(b)

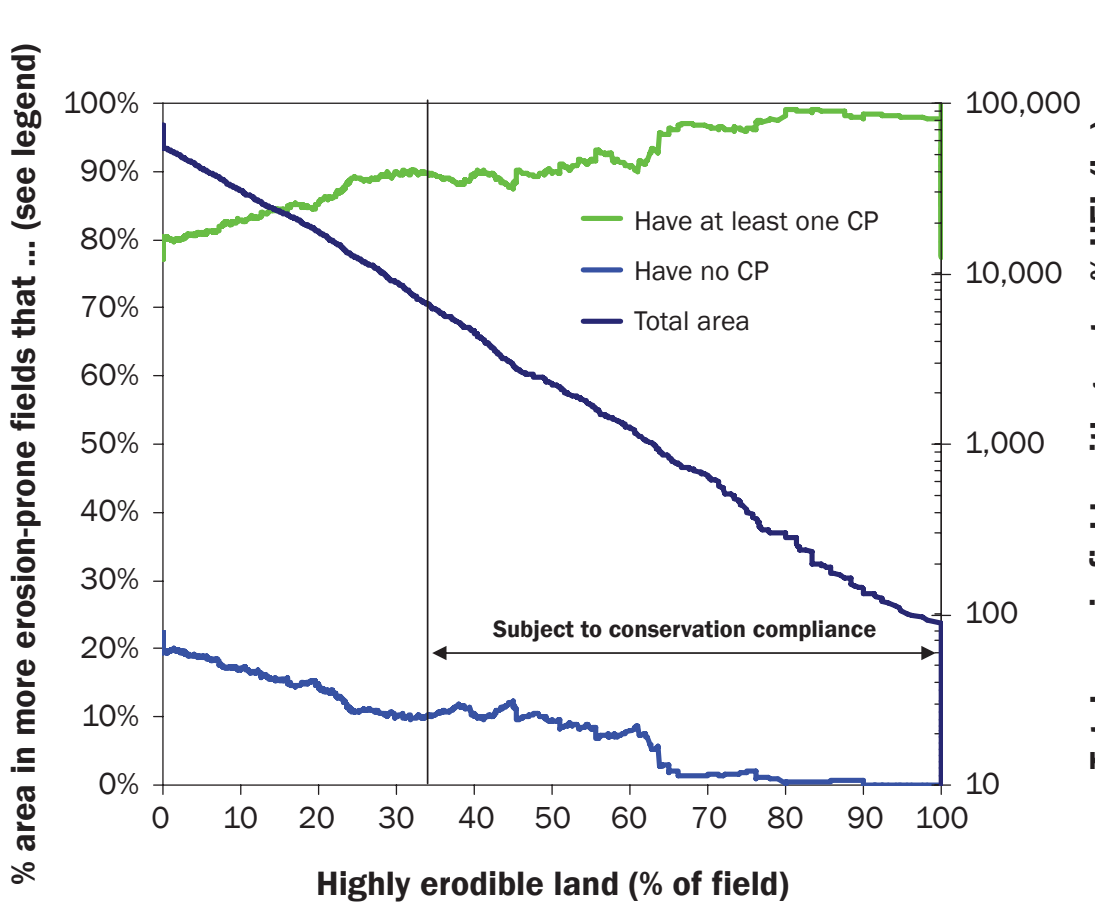

Note: $\mathrm{HEL}=$ highly erodible land. $\mathrm{CRP}=$ Conservation Reserve Program. $\mathrm{CP}=$ conservation practice. 
Table 3

Extent of conservation practices in the lowa River's South Fork watershed and its sensitive locations (near stream, highly erodible land).

\begin{tabular}{|c|c|c|c|c|}
\hline \multirow[b]{2}{*}{ Practice or condition } & \multicolumn{4}{|c|}{ ha (\% of agricultural land) } \\
\hline & $\begin{array}{l}\text { Entire } \\
\text { watershed }\end{array}$ & $\begin{array}{l}\text { Within } \\
200 \mathrm{~m} \text { of stream (B) }\end{array}$ & $\begin{array}{l}>\mathbf{3 4} \% \text { highly } \\
\text { erodible land (A) }\end{array}$ & $A+B$ \\
\hline \multicolumn{5}{|l|}{ Conservation using perennial species: } \\
\hline Conservation Reserve Program & $2,619(3.5 \%)$ & $1,467(5.7 \%)$ & $690(10.4 \%)$ & $474(13.1 \%)$ \\
\hline Perennial rotation & $758(1.0 \%)$ & $464(1.8 \%)$ & $283(4.3 \%)$ & $202(5.6 \%)$ \\
\hline \multicolumn{5}{|l|}{ Combination of tillage and structures } \\
\hline No tillage and grassed waterway and/or terrace & $1,912(2.6 \%)$ & 887 (3.5\%) & $688(10.4 \%)$ & $337(9.3 \%)$ \\
\hline Mulch or ridge tillage and grassed waterway and/or terrace & $8,514(11.4 \%)$ & $3,190(12.5 \%)$ & $1,449(21.9 \%)$ & $704(19.5 \%)$ \\
\hline Structures: Grassed waterway and/or terrace & $15,099(20.2 \%)$ & $5,658(22.2 \%)$ & $2,851(43.1 \%)$ & $1,480(41.0 \%)$ \\
\hline \multicolumn{5}{|l|}{ No observed practice: conventional tillage and } \\
\hline no structural conservation practice recorded* & $15,698(21.0 \%)$ & $4,725(18.5 \%)$ & $658(9.9 \%)$ & $355(9.8 \%)$ \\
\hline
\end{tabular}

\section{Figure 5}

Map of the conservation-targeted lands considered in table 3.

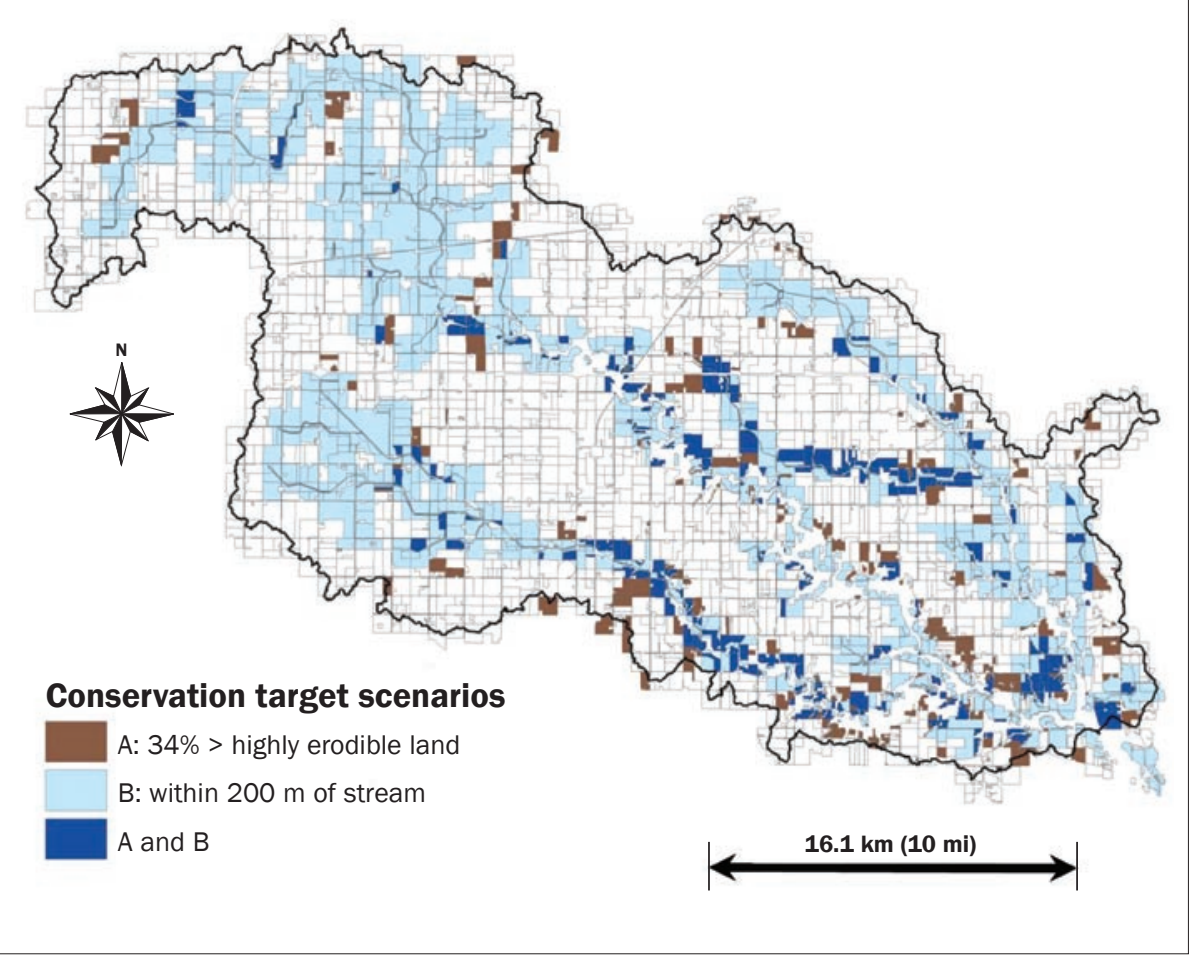

management might help mitigate any ongoing impact of this legacy source of sediment and accompanying contaminants. There are ongoing assessment and restoration efforts in the watershed's stream corridor, with active involvement of the SFWA.

Second, despite the widespread presence of beneficial erosion control practices, there are several issues raised by the CP inventory data that may point the way to further improvements in water quality. The difficulty producers have in maintaining crop residue following soybean (table 2) may need greater recognition, especially if and where soil $\mathrm{P}$ accumulation resulting from manure application has occurred. Alternatives to address this might include companion or cover crops, for which management prescriptions are improving (Miguez and Bollero 2005). Viability of manure applications into cover crops is a subject of ongoing research in Iowa. Such practices could address erosion control needs, reduce nutrient losses (Kaspar et al. 2007), and perhaps provide biomass for energy production or livestock feed. The limited extent of nutrient management plans in the watershed (table 1) could also be addressed. Although an additional 
number of the swine confinements in the watershed have nutrient management plans approved by the state, available data on these plans have only identified the source facilities and not the agricultural fields receiving manure. Estimated crop removal rates of N, approximately $200 \mathrm{~kg} \mathrm{ha}^{-1}\left(179 \mathrm{lb} \mathrm{ac}^{-1}\right)$, typically set the application rate in these plans. However, maximum economic returns for corn generally occur at $\mathrm{N}$ rates of $170 \mathrm{~kg} \mathrm{ha}^{-1}$ $\left(152 \mathrm{lb} \mathrm{ac}^{-1}\right)$ or less (Sawyer et al. 2006). Better documentation of actual rates of fertilizer and manure applications and crop removal, which we had no information about, would help efforts to evaluate and improve nutrient management in the watershed. An Iowa Soybean Association project in the watershed, in collaboration with the SFWA, has gathered some of this information on a sitespecific basis. Also, better technologies for manure storage and handling would provide the livestock industry greater flexibility for fully utilizing the value of manure nutrients.

Third, and perhaps most importantly, the conservation systems placed in this watershed are not targeted at the most important transport pathway. Nearly all the CPs documented in our survey are aimed at erosion control and target surface runoff as the mechanism of pollutant transport. In the South Fork watershed, however, tile drainage dominates the hydrologic budget (Green et al. 2006), and provides the dominant pathway for delivery of nitrate and dissolved phosphorus to streams (Tomer et al. 2008). Part of the problem is there are fewer CPs designed to target tile drainage than there are to target surface runoff. Two practices that have been advocated and researched include controlled drainage ( $\mathrm{Ng}$ et al. 2002; Fisher et al. 1999) and nutrient removal wetlands (Kovacic et al. 2000). Controlled drainage may be feasible in some parts of the South Fork, but it would probably require significant re-engineering of the drainage infrastructure. This practice, which is most appropriate for near-level terrain $(<0.5 \%$ slope $)$, is difficult to apply to complex moraine landscapes. Nutrientremoval wetlands are a more feasible practice, but the current extent of wetlands in the watershed is limited (table 1). Tomer et al. (2003), in analysis of possible wetland sites in the South Fork's Tipton Creek, suggested $40 \%$ of that subbasin's drainage area could be routed through constructed wetlands.

To summarize briefly, nutrient management, nutrient-removal wetlands, and changes in cropping systems that increase soil protection and reduce nutrient losses following soybean harvest are among the types of changes that should lead to quantifiable improvements in the South Fork's water quality. Research information in these areas is progressed enough to begin to implement changes, although financial incentives may be required. Other areas where ongoing research can inform future conservation efforts would be improved manure processing and storage technologies, controlled drainage, and riparian corridor assessment and management.

\section{Acknowledgements}

Our thanks to the State Office Staff of the USDA NRCS in Des Moines, Iowa, for facilitating the conservation practice inventory, which was aided by local NRCS and Farm Service Agency staff in Hardin, Hamilton, Franklin, and Wright Counties.

\section{References}

Burkart, M., D. James, M. Liebman, and C. Herndl. 2005. Impacts of integrated crop-livestock systems on nitrogen dynamics and soil erosion in western Iowa watersheds. Journal of Geophysical Research 110:G01009.

Claassen, R., L. Hansen, M. Peters, V. Breneman, M. Weinberg, A. Cattaneo, P. Feather, D. Gadsby, D. Hellerstein, J. Hopkins, P. Johnston, M. Morehart, and M. Smith. 2001. Agri-environmental policy at the crossroads: Guideposts on a changing landscape. Agricultural Economic Report Number 794. Washington DC: USDA Economic Research Service.

Daverede, I.C., R.G. Hoeft, E.D. Nafziger, D.G. Bullock, J.J. Warren, and L.C. Gonzini. 2004. Phosphorus runoff from incorporated and surface-applied liquid swine manure and phosphorus fertilizer. Journal of Environmental Quality 33(4):1535-1544.

Environmental Systems Research Institute. 2002. ARC/ INFO 8.2 User's Guide. Redlands, CA: Environmental Systems Research Institute.

Fisher, M.J., N.R. Fausey, S.E. Subler, L.C. Brown, and P.M. Bierman. 1999. Water table management, nitrogen dynamics, and yields of corn and soybean. Soil Science Society of America Journal 63(6):1786-1795.

Gowda, P.H., D.J. Mulla, and B.J. Dalzell. 2003. Examining the targeting of conservation tillage practices to steep vs. flat landscapes in the Minnesota River basin. Journal of Soil and Water Conservation 58(1):53-57.

Green, C.H., M.D. Tomer, M. Di Luzio, and J.G. Arnold. 2006. Hydrologic evaluation of the Soil and Water Assessment Tool for a large tile-drained watershed in Iowa. Transactions American Society of Agricultural and Biological Engineers 49(2):413-422.

Hatch, L.K., A. Mallawatantri, D. Wheeler, A. Gleason, D. Mulla, J. Perry, K.W. Easter, R. Smith, L. Gerlach, and P. Brezonik. 2001. Land management at the major watershed - agroecoregion intersection. Journal of Soil and Water Conservation 56(1):44-51.

Iowa State University. 2002. Iowa Geographic Map Server. Ames, IA: Geographic Information Systems Support and Research Facility, Iowa State University. http:// ortho.gis.iastate.edu/
Johansson, R.C., and J. Randall. 2003. Watershed abatement costs for agricultural phosphorus. Water Resources Research. 39(4):1088.

Johnson, J.M.-F., R.R. Allmaras, and D.C. Reicosky. 2006. Estimating source carbon from crop residues, roots and rhizodeposits using the national grain-yeild database. Agronomy Journal 98(3):622-636.

Kaspar, T.C., D.B. Jaynes, T.B. Parkin, and T.B. Moorman. 2007. Rye cover crop and gamagrass strip effects on $\mathrm{NO}_{3}$ concentration and load in tile drainage. Journal of Environmental Quality 36(5):1503-1511.

Kovacic, D.A., M.B. David, L.E. Gentry, K.M. Starks, and R.A. Cooke. 2000. Effectiveness of constructed wetlands in reducing nitrogen and phosphorus export from agricultural tile drainage. Journal of Environmental Quality 29(4):1262-1274.

Lorimer, J.C., W. Powers, and A. Sutton. 2000. Manure Characteristics. MWPS-18. Ames, IA: Midwest Plan Service.

Lorimer, J.C. 2003. Managing Manure Nutrients for Crop Production. Publication PM 1811 (revised). Ames, IA: Extension Service, Iowa State University.

Lory, J.A., R.E. Massey, J.M. Zulovich, J.A. Hoehne, A.M. Schmidt, M.C. Carlson, and C.D. Fulhage. 2004. An assessment of nitrogen-based manure application rates on 39 US swine operations. Journal of Environmental Quality 33:1106-1113.

Miguez, F.E., and G.E. Bollero. 2005. Review of corn yield response under winter cover cropping systems using meta-analytic methods. Crop Science 45(6):2318-2329.

Ng, H.Y.F., C.S. Tan, C.F. Drury, and J.D. Gaynor. 2002. Controlled drainage and subirrigation influences tile nitrate loss and corn yields in a sandy loam soil in southwestern Ontario. Agriculture, Ecosystems, and Environment 90(1):81-88.

Nowak, P.J., and P.E. Cabot. 2004. The human dimension of resource management programs. Journal of Soil and Water Conservation 59(6):128A-135A

Renschler, C.S., and T. Lee. 2005. Spatially distributed assessment of short- and long-term impacts of multiple best management practices in agricultural watersheds. Journal of Soil and Water Conservation 60(6):446-456.

Richards, R.P., and D.B. Baker. 2002. Trends in water quality in LEASEQ rivers and streams (northwestern Ohio), 1975-1995. Journal of Environmental Quality 31(1):90-96

Richards, R.P., D.B. Baker, and D.J. Eckert. 2002. Trends in agriculture is the LEASEQ watersheds, 1975-1995. Journal of Environmental Quality 31(1):17-24.

Robinson, J.R., and T.L. Napier. 2002. Adoption of nutrient management techniques to reduce hypoxia to the Gulf of Mexico. Agricultural Systems 72(3):197-213

Sawyer, J., E. Nafziger, G. Randall, L. Bundy, G. Rehm, and B. Joern. 2006. Concepts and Rationale for Regional Nitrogen Rate Guidelines for Corn. Publication 2015. Ames, IA: Extension Service, Iowa State University.

Schnepf, M., and C. Cox, ed. 2007. Environmental Benefits of Conservation on Cropland: The Status of our Knowledge. Ankeny, IA: Soil and Water Conservation Society.

Sharpley, A.N., P.J.A. Kleinman, R.W. McDowell, M. Gitau, and R.B. Bryant. 2002. Modeling phosphorous transport in agricultural watersheds: Processes and possibilities. Journal of Soil and Water Conservation 57(6):425-439

Tomer, M.D., D.E. James, and T.M. Isenhart. 2003. Optimizing the placement of riparian practices in a watershed using terrain analysis. Journal of Soil and Water Conservation 58(4):198-206. 
Tomer, M.D., T.B. Moorman, and C.H. Green. 2008. Assessment of the Iowa River's South Fork watershed: Part 1. Water quality. Journal of Soil and Water Conservation 63(6):360-370.

Trimble, S.W. 1999. Decreased rates of alluvial sediment storage in the Coon Creek Basin, Wisconsin, 19751993. Science 285:1244-1246

USDA NASS (National Agricultural Statistics Service). 2007. Cropland Data Layer. Washington, DC: USDA National Agricultural Statistics Service. http://www.nass.usda. gov/research/Cropland/SARS1a.htm.

Walter, T., M. Dosskey, M. Khanna, J. Miller, M. Tomer, and J. Weins. 2007. The science of targeting within landscapes and watersheds to improve conservation effectiveness. In Managing Agricultural Landscapes for Environmental Quality: Strengthening the Science Base, ed. M. Schnepf and C. Cox, 63-89. Ankeny, IA: Soil and Water Conservation Society.

Yang, W., M. Khanna, and R. Farnsworth. 2005. Effectiveness of conservation programs in Illinois and gains from targeting. American Journal of Agricultural Economics 87(5):1248-1255. 